\title{
FREKUENSI PENYIRAMAN LARUTAN URIN DOMBA TERHADAP TINGGI TANAMAN, JUMLAH DAUN DAN PRODUKSI SEGAR HIDROPONIK FODDER JAGUNG (Zea mays)
}

\author{
Tri Ida Wahyu Kustyorini ${ }^{1}$, Aju Tjatur Nugroho Krisnaningsih ${ }^{1}$ dan Didakus Santitores ${ }^{1}$ \\ Fakultas Peternakan, Universitas Kanjuruhan Malang \\ Email: triida@unikama.ac.id
}

\begin{abstract}
ABSTRAK
Tujuan dari penelitian ini adalah untuk mengetahui pengaruh frekuensi penyiraman larutan urin domba terhadap tinggi tanaman, jumlah daun dan produksi segar hidroponik fodder jagung (Zea mays). Materi yang digunakan dalam penelitian ini adalah biji jagung sebanyak 3.750 biji, urin domba dan air. Metode yang digunakan dalam penelitian ini adalah percobaan lapang menggunakan Rancangan Acak Lengkap (RAL) yang terdiri dari 3 perlakuan dan 5 ulangan. Perlakuan penelitian terdiri dari P1 (penyiraman 1 kali /hari), P2 (penyiraman 2 kali /hari) dan P3 (penyiraman $3 \mathrm{kali} /$ hari) dengan larutan urin domba 10\%. Variabel yang diamati pada penelitian ini adalah tinggi tanaman, jumlah daun dan produksi segar. Analisis yang digunakan adalah analisis ragam (ANOVA) jika terdapat pengaruh maka dilanjutkan dengan uji BNT.Berdasarkan hasil penelitian menunjukkan bahwa frekuensi penyiraman larutan urin domba memberikan pengaruh yang tidak nyata $(\mathrm{P}>0,05)$ terhadap tinggi tanaman dan jumlah daun serta memberikan pengaruh yang sangat nyata $(\mathrm{P}<0,01)$ terhadap produksi segar hijauan. Tinggi tanaman tertinggi pada P2 (36,76 cm), jumlah daun tertinggi pada P2 (3,40 helai) dan produksi berat segar tertinggi pada P2 (374,80 gram). Kesimpulan dari penelitian ini adalah penyiraman larutan urin domba 2 kali/hari memberikan hasil yang terbaik terhadap tinggi tanaman, jumlah daun dan produksi segar hidroponik fodder jagung (Zea mays).

Kata kunci: Urin domba, fodder jagung, tinggi tanaman, jumlah daun dan produksi hijauan segar.
\end{abstract}

The purpose of this study was to determine the effect of watering frequency of sheep urine solution on plant height, number of leaves and plant production on corn fodder (Zea mays). The material used in this study was 3.750 corn, sheep urine and water. The method used in this study was a field experiment using a Completely Randomized Design (CRD) consisting of 3 treatments and 5 replications. The research treatment consisted of P1 (watering 1 time /day), P2 (watering 2 times /day) and P3 (watering 3 times /day) with 10\% sheep urine solution. The variables observed in this study were plant height, number of leaves and plant production. The analysis used was analysis of variance if there was an effect then continued with the LSD test. Based on the results of the study showed that the frequency of watering the urine solution of sheep gave no significant effect $(\mathrm{P}>0.05)$ on plant height, number of leaves and gave a very significant effect $(\mathrm{P}<0.01)$ on plant production. The highest plant height in $\mathrm{P} 2(36.76 \mathrm{~cm})$, the highest number of leaves in $\mathrm{P} 2$ (3.40 strands) and the highest plant production in P2 (374.80 grams). The conclusion of this study is the watering of sheep urine solution 2 times a day giving the best results on plant height, leaf number and fresh hydroponic production of corn fodder (Zea mays).

Keywords: sheep urine, corn fodder, plant height, number of leaves and plant production

\section{Pendahuluan}

Salah satu faktor keberhasilan suatu peternakan adalah ketersediaan hijauan yang sangat cukup untuk memenuhi kebutuhan pakan ternak. Hijauan merupakan sumber pakan yang paling penting dalam memenuhi kebutuhan hidup pokok, produksi dan reproduksi, karena pakan yang dikonsumsi oleh ternak sebagian besar dalam bentuk hijauan. Akan tetapi ketersediaan hijauan sangat terbatas. Pada musim hujan ketersediaan hijauan sangat melimpah, namun pada saat musim kemarau ketersediaan hijauan sangat 


\section{Jurnal Sains Peternakan}

Volume 8 No. 1, Juni 2020, pp:57-65

ISSN 2579-4450

terbatas. Selain itu lahan yang begitu sempit karena jumlah penduduk semakin meningkat, juga menjadi faktor pembatas ketersediaan hijauan pakan. Oleh karena itu dibutuhkan teknologi yang dapat menjadi solusi untuk memenuhi kebutuhan hijauan dengan memproduksi hijauan berkesinambungan dengan teknologi alternatif untuk memproduksi pakan hijauan ternak.

Hidroponik merupakan salah satu alternatif untuk mengatasi permasalahan tersebut. Hidroponik merupakan istilah yang digunakan untuk bercocok tanam tanpa menggunakan tanah sebagai media tanamnya serta menggunakan campuran nutrisi esensial yang dilarutkan di dalam air (Sudarmodjo, 2008). Teknik hidroponik memiliki kemampuan untuk menghasilkan produk berkualitas selain itu sistem hidroponik tidak tergantung dengan musim sehingga tanaman dapat ditanam sepanjang tahun dan dapat ditanam di lahan yang sempit dengan sistem green house.Budidaya tanaman dengan sistem hidroponik umumnya dilakukan di dalam green house(Suhardiyanto, 2009). Salah satu teknologi budidaya pakan ternak dapat diterapkan dengan sistem hidroponik adalah fodder.

Fodder merupakan keseluruhan dari bagian tanaman, baik dalam kondisi yang masih segar maupun sudah mengalami pengolahan tertentu dan diberikan untuk ternak sebagai pakan hijauan. Menurut Ahmed (2011), fodder adalah istilah tanaman yang digunakan sebagai pakan misalnya berbahan baku jagung. Jagung merupakan tanaman yang mampu beradaptasi dengan baik meskipun terdapat faktor pembatas pertumbuhan dan produksi. Keunggulan dari jagung yang ditanam dengan sistem hidroponik yaitu pertumbuhan tanaman jagung yang cepat sehingga dapat diproduksi dalam waktu yang relatif singkat. Pertumbuhan dan perkembanngan jagung di pengaruhi oleh faktor internal (genetik dan hormon) dan faktor eksternal (faktor lingkungan) di antaranya suhu, kelembaban, cahaya, air dan unsur hara.Salah satu upaya untuk pemenuhan unsur hara yakni dengan pemanfaatan urin domba.

Urin domba merupakan salah satu sumber pupuk organik yang kaya $\mathrm{N}$ yang berpotensi sebagai pengganti pupuk urea. Urin ternak merupakan salah satu substrat yang mengandung Auksin dan Asam Giberelin (GA) serta Kinetin (Astutik, 2013). Auksin berperan sebagai pemacu proses pemanjangan sel sedangkan giberelin berperan dalam merangsang perkembangan dan perkecambahan embrio. Kadar hormon auksin pada urin domba yaitu 0 sampai 418 ppm sedangkan giberlinnya 0 sampai 2432 ppm (Nasution, 2014). Menurut (Saleh 2004), kandungan unsur hara urin domba lebih baik dibandingkan kandungan unsur hara pada fesenya. Kandungan N, P dan K pada urin domba berturutturut sebesar $1,35 \%, 0,5 \%$ dan $2,10 \%$, sedangkan unsur hara pada fesessnya sebesar 


\section{Jurnal Sains Peternakan}

Volume 8 No. 1, Juni 2020, pp:57-65

ISSN 2579-4450

$0,75 \%, 0,50 \%$ dan $0,0 \%$. Selain hara, hal yang perlu diperhatikan dalam budidaya tanaman yakni ketersediaan air.

Penyiraman merupakan suatu hal yang tidak dapat dilepas didalam menjaga serta merawat agar tanaman dapat tumbuh dengan subur. Kebutuhan air yang cukup merupakan salah satu hal yang sangat penting. Frekuensi penyiraman menjadi salah satu hal yang perlu diperhatikan, karena daya absorbsi dan durasi absorbsi air pada tumbuhan bervariasi. Penyiraman secara manual biasanya menggunakan gayung dan sprayer.Pada awal pertumbuhan setiap polibag disiram dengan larutan hara sebanyak $100 \mathrm{ml}$. Frekuensi penyiraman dapat dilakukan 1-2 kali/hari (Karsono, Sudarmodjo, dan Sutiyoso, 2002).

Berdasarkan hal tersebut, maka perlu dilakukan penelitian tentang frekuensi penyiraman larutan urin domba terhadap tinggi tanaman, jumlah daun dan produksi segar hidroponik fodder jagung (Zea mays).

\section{Materi Dan Metode}

Materi yang digunakan dalam penelitian ini adalah biji jagung kuning sebanyak 3.750 biji, air dan urin domba. Metode yang digunakan dalam penelitian ini adalah percobaan lapang. Rancangan yang digunakan adalah Rancangan Acak Lengkap (RAL) dengan frekuensi penyiraman menggunakan larutan urin domba $10 \%$ sebagai perlakuan yang terdiri dari 3 perlakuan dan 5 ulangan

Perlakuan dalam penelitian ini yaitu:

P1 : Penyiraman 1 kali/hari

P2 : Penyiraman 2 kali/hari

P3 : Penyiraman 3 kali/hari

Variabel yang digunakan dalam penelitian ini adalah tinggi tanaman, jumlah daun dan produksi segarfodder jagung (Zea mays). Data yang diperoleh selama penelitian dianalisis dengan menggunakan analisis varian apabila pada hasil analisis terdapat pengaruh maka dilanjutkan dengan uji BNT.

\section{Hasil Dan Pembahasan}

Berdasarkan hasil penelitian frekuensi penyiraman larutan urin domba memberikan pengaruh yang tidak nyata $(\mathrm{P}>0,05)$ terhadap tinggi tanaman dan jumlah daun serta memberikan pengaruh yang sangat nyata $(\mathrm{P}<0,01)$ terhadap produksi segar hijauan. Hasil penelitian dapat dilihat pada tabel 1. 


\section{Jurnal Sains Peternakan}

Volume 8 No. 1, Juni 2020, pp:57-65

ISSN 2579-4450

Tabel 1. Hasil Data Penelitian

\begin{tabular}{lccc}
\hline Perlakuan & \multicolumn{3}{c}{ Parameter } \\
\cline { 2 - 4 } & $\begin{array}{c}\text { Tinggi } \\
\text { Tanaman } \\
(\mathrm{cm})\end{array}$ & Jumlah Daun (helai) & $\begin{array}{c}\text { Produksi Hijauan } \\
\text { Segar (gram) }\end{array}$ \\
\cline { 2 - 4 } P1 & $35,92 \pm 0,81$ & $3,20 \pm 0,45$ & $355,80 \pm 6,61^{\mathrm{b}}$ \\
P2 & $36,76 \pm 4,17$ & $3,40 \pm 0,55$ & $374,80 \pm 7,76^{\mathrm{c}}$ \\
P3 & $33,70 \pm 2,68$ & $3,20 \pm 0,45$ & $317,00 \pm 7,42^{\mathrm{a}}$ \\
\hline
\end{tabular}

Keterangan: Notasi ${ }^{\text {a-c }}$ diatas adalah notasi menunjukkan pengaruh adanya perbedaan yang sangat nyata $(\mathrm{P}<0,01)$ antarperlakuan.

\section{Tinggi Tanaman}

Berdasarkan hasil tabel analisis sidik ragam menunjukkan bahwa frekuensi penyiraman larutan urin domba menunjukkan adanya perbedaan yang tidak nyata $(\mathrm{P}>0,05)$ terhadap tinggi tanaman. Rataan tinggi tanaman tertinggi sampai terendah secara berurutan adalah P2, P1, P3 dengan nilai P2 36,76 cm, P1 35,92 cm dan P3 33,70 $\mathrm{cm}$. Hasil tinggi tanaman fodder jagung menunjukkan tidak ada perbedaan yang nyata antar perlakuan. Tinggi tanaman tidak dipengaruh oleh frekuensi penyiraman, adanya interval penyiraman yang berbeda tidak mampu menyebabkan peningkatan inisiasi tinggi tanaman. Hal ini disebabkan proses pemeliharaan bibit tanaman setelah tumbuh pada semua perlakuan sama.

Faktor yang mempengaruhi rendahnya tinggi tanaman dengan frekuensi penyiraman larutan urin domba adalah faktor internal dan eksternal. Faktor internal meliputi gen dan hormon sedangkan faktor eksternal meliputi unsur hara, air, suhu, cahaya dan kelembaban. Menurut Fahmi, dkk (2013) faktor eksternal adalah faktor yang berasal dari luar tumbuhan atau faktor eksternal yang mencakup cahaya sinar matahari, kelembaban udara, nutrisi, kadar air, oksigen atau karbondioksida, $\mathrm{pH}$ atau sederajat keasaman, kepadatan populasi dan media tanam tumbuhan. Pada penelitian ini faktor internal tidak berpengaruh karena benih yang ditanam yaitu benih yang sama. Tetapi perbedaan tersebut diakibatkan karena faktor eksternal seperti unsur hara dimana urin domba yang diaplikasikan pada tanaman tidak bisa berinteraksi dengan baik sehingga tidak memberikan hasil yang berbeda terhadap tinggi tanaman. Sejalan dengan pendapat Rizqiani, dkk (2007) menjelaskan bahwa tanaman membutuhkan unsur hara untuk melakukan proses-proses metabolisme, terutama pada masa vegetatif. Menurut Marsono dan Sigit (2001), unsur hara makro dan mikro sangat dibutuhkan oleh tanaman, terutaman $\mathrm{N}$ diperlukan untuk membentukan klorofil yang diperlukan dalam proses fotosintesis dan memacu pertumbuhan vegetatif tanaman, phosphor $(\mathrm{P})$ berperan membentukan batang 


\section{Jurnal Sains Peternakan}

Volume 8 No. 1, Juni 2020, pp:57-65

ISSN 2579-4450

dan daun, sehingga dapat memenuhi kebutuhan tanaman jagung, sedangkan kalium (K) berperan sebagai pengatur proses fisiologis tanaman seperti fotosintetis, akumulasi, translokasi, transportasi karbihidrat, membuka membentuk stomata, atau mengatur distribusi air dalam jaringan dan sel.

Faktor lain yang mempengaruhi tinggi tanaman fodder jagung adalah air, suhu dan cahaya sehingga memberikan hasil yang signifikan terhadap tinggi tanaman. Hal ini sesuai dengan pendapat Aprianto (2012) dengan meningkatnya proses fotosintesis, maka produksi tanaman juga akan meningkat. Ditambah oleh Sutedjo, (2002) semakin tinggi tanaman dan banyak jumlah cabang, semakin banyak daun dan lebar luas daun membuat tanman lebih banyak menyerap unsur hara dan sinar matahari, dengan demikian proses fotosintesis akan berjalan lebih baik sehingga karbohidrat dan protein yang dihasilkan akan lebih banyak dan akan disebarkan ke seluruh bagian tanaman sehingga berat kering hijauan akan meningkat. Jagung merupakan tanaman yang tahan terhadap kekeringan dan dapat tumbuh dengan baik pada lingkungan dengan kelembaban udara 42-80\%. Ditambah oleh Barnito (2009) tanaman jagung membutuhkan kelembaban udara sedang sampai dengan tinggi (50\%-80\%) agar keseimbangan metabolisme tanaman dapat berlangsung dengan optimal.

\section{Jumlah Daun}

Berdasarkan sidik ragam menujukkan bahwa frekuensi penyiraman urin domba yang berbeda memberikan perbedaan yang tidak nyata $(\mathrm{P}>0,05)$ terhadap jumlah daun fodder jagung. Rataan jumlah daun secara berurutan P2 3,40 helai, P1 3,20 helai dan P3 3,20 helai. Hasil yang tidak nyata ini disebabkan waktu pembentukan daun pada tanaman graminae relatif sama yakni 3-4 hari. Hal ini berbeda dengan pendapat Subekti, dkk (2010) menyatakan bahwa daun pertama mulai muncul setelah tanaman umur 9 hari. Jumlah daun berhubungan dengan pertumbuhan batang atau tinggi tanaman dimana batang tersusun dari ruas yang merentang diantara buku-buku batang tempat melekatnya daun semakin tinggi tanaman semakin banyak pula jumlah daun pada tanaman tersebut. Pernyataan ini didukung Gardner, dkk (2008), yang menyatakan bahwa batang tanaman jagung tersusun atas ruas yang merentang diantara buku-buku batang tempat melekatnya daun.

Faktor-faktor yang mempengaruhi produktivitas tanaman yaitu faktor internal (genetik dan hormon) dan eksternal (kematangan biji dan lingkungan). Menurut Fahmi dkk (2013) faktor eksternal adalah faktor yang berasal dari luar tumbuhan atau faktor eksternal yang mencakup cahaya sinar matahari, kelembaban udara, nutrisi, kadar air, 


\section{Jurnal Sains Peternakan}

Volume 8 No. 1, Juni 2020, pp:57-65

ISSN 2579-4450

oksigen atau karbondioksida, $\mathrm{pH}$ atau sederajat keasaman, kepadatan populasi dan media tanam tumbuhan. Jumlah daun yang tidak berbeda nyata ini dipengaruhi oleh intensitas cahaya matahari pada saat penelitian tanaman kurang mendapatkan cahaya sinar matahari sehingga pertumbuhan tanman tidak memberikan pengaruh antar perlakuan. Pernyataan ini sesuai yang disampaikan oleh Kurniatyet, dkk (2010) menyatakan bahwa intensitas cahaya yang terlalu rendah akan menghasilkan produk fotosintesis yang tidak maksimal, sedangkan intensitas cahaya yang terlalu tinggi akan berpengaruh terhadap aktivitas selsel stomata daun dalam mengurangi transpirasi sehingga mengakibatkan terhambatnya pertumbuhan tanaman. Ditambah Septia (2016), menjelaskan bahwa daun memiliki klorofil yang berperan dalam melakukan fotosintesis semakin banyak jumlah daun, maka tempat untuk melakukan fotosintensis lebih banyak dan hasilnya optimal.

Berdasarkan hasil penelitian jumlah daun tertinggi dicapai oleh perlakuan P2 yaitu 3,40 helai. Pada umur 10-14 hari setelah kecambah jumlah daun yang terbuka sempurna adalah sekitar 3-5 helai daun, suhu lingkungan sangat mempengaruhi titik laju pertumbuhan. Suhu rendah akan memperlambat keluar daun, meningkat jumlah daun (Mc Wiliams, et al, 2000).

\section{Produksi Hijauan Segar}

Hasil sidik ragam menunjukkan bahwa frekuensi penyiraman larutan urin domba dapat memberikan pengaruh yang sangat nyata $(\mathrm{P}<0,01)$ terhadap produksi segar hijauan fodder jagung. Berdasarkan hasil perhitungan rata-rata produksi segar hijauan tertinggi dicapai oleh perlakuan P2 dengan berat segar 374,80 gram sedangkan terendah dicapai oleh perlakuan P3 317,00 gram. Berdasarkan tabel 1 maka dapat dilihat hasil perlakuan tertinggi dan terendah secara berurutan P2, P1 dan P3 dengan nilai P2 374,80 gram, P1 355,80 gram dan P3 317,00 gram. Pada perlakuan P2 dengan (penyiraman 2x/hari) memberikan hasil terbaik terhadap berat segar dengan nilai 374,80 , hal ini karena pada perlakuan P2 memiliki nilai persentase perkecambahan yaitu $94,00 \%$ dan perkecambahannormal yaitu 227,40\% (Kustyorini, dkk., 2019) dari data tersebut terlihat bahwa pertumbuhan benihnya cukup baik sehingga dapat memberikan berat segar yang tertinggi. Menurut Sarah dkk, (2016) bahwa standar keberhasilan perkecambahan 80\% dan hasil standar dapat menjadi acuan untuk melakukan penanaman fodder jagung (Zea mays). Menurut Sutopo, (2010) daya berkecambah benih memberikan informasi kepada pemakai benih akan kemampuan benih tumbuh normal menjadi tanaman yang berproduksi wajar dalam keadaan lapangan yang serba optimum. Menurut Prihartini, 


\section{Jurnal Sains Peternakan}

Volume 8 No. 1, Juni 2020, pp:57-65

ISSN 2579-4450

(2014) produksi fodder jagung yang dihasilkan dari biji jagung sebanyak 713 gram menghasilkan sekitar 2 kali lipat hijauan segar dengan umur 13 hari.

Perlakuan P1 (penyiraman 1x/hari) memberikan hasil yang rendah dikarenakan penyiraman dengan jumlah air yang terlalu banyak mempengaruhi proses perkecambahan pada benih sehingga daya serap air oleh biji tidak mampu untuk sampai kecambah. Selain itu faktor lingkungan juga dapat mempengaruhi berat segar hijauan. Pernyataan ini didukung oleh Herdiawan dan Krisnan, (2014) kondisi lingkungan yang sesuai dengan jenis tanaman yang dibudidayakan dapat mendukung pertumbuhan tanaman yang optimal dan perawatan seperti pemupukan dapat meningkat hasil panen. Sedangakan pada perlakuan P3 dengan (penyiraman 3x/hari) memberikan hasil yang sangat rendah terhadap berat segar hijauan, hal tersebut karena penyiraman yang terlalu sering mengakibatkan benih pada media mengalami pembusukan karena kelebihan air sehingga persentase perkecambahan dan perkecambahan normal pada media tanaman tidak memberikan hasil yang optimal. Menurut Djajadi, dkk (2010) bahwa pemberian air dengan frekuensi penyiraman $2 \mathrm{x} /$ hari pada bibit tanaman jarak pagar menghasilkan proporsi makro agregat yang lebih tinggi dibandingkan dengan frekuensi pemberian air $3 x /$ hari, biji membutuhkan air 30\% dari berat biji itu sendiri. Cahaya merupakan salah satu faktor mempengaruhi perkecambahan. Pernyataan ini didukung oleh Finch-Savage dan Leubner-Metzger, (2006) mengatakan bahwa cahaya dapat menstimulasikan perkecambahan dan juga dapat menghentikan dormansi.

Berdasarkan hasil penelitian frekuensi penyiraman larutan urin domba memberikan berat segar hijauan tertinggi yaitu pada perlakuan P2 dengan berat 374,80 gram. Dengan perbandinagan 250 biji jagung mencapai 63 gram dapat menghasilkan berat segar hijauan 374,80 gram. Hasil penelitian ini sesuai dengan penelitian Sneath and Mclntosh, (2003) bahwa perbandingan biji jagung $1 \mathrm{~kg}$ yang ditanam dengan sistem hidroponik dapat menghasilkan 6 sampai $10 \mathrm{~kg}$ hijauan segar.

\section{Kesimpulan}

Berdasarkan hasil penelitian maka dapat disimpulkan bahwa frekuensi penyiraman larutan urin domba dua kali sehari memberikan hasil yang terbaik terhadap tinggi tanaman, jumlah daun dan produksi segar hijauan hidroponik fodder jagung (Zea mays).

\section{Daftar Rujukan}

Ahmed, K. 2011. Fodder Plants, Everything you to know-A Featured Article. 


\section{Jurnal Sains Peternakan}

Volume 8 No. 1, Juni 2020, pp:57-65

ISSN 2579-4450

Aprianto, D. 2012. Hubungan Pupuk Kandang dan NPK Terhadap Bakteri Azotobacter dan Azosprillum.Program Pasca Sarjana. Institut Pertanian Bogor.

Astutik. 2013. Pengaruh Zat Giberelin Terhadap Perkecambahan Biji Kaliandra. Universitas Airlangga

Barnito, N. 2009.Budidaya Tanaman Jagung. Suka Abadi. Yogyakarta.

Djajadi.Helianto.B dan Hidayah, N. 2010.Pengaruh media tanam dan frekuensi pemberian air terhadap sifat fisik, kimia dan biologi tanah serta pertumbuhan jarak pagar.Jurnal Littri. 16(2):64-69

Fahmi A, Syamsudin, Utami SNH, Radjagukguk B. 2010. Pengaruh interaksi hara nitrogen dan fosfor terhadap pertumbuhan tanaman jagung (Zea mays L) pada tanah regosol dan latosol.Berita Biologi. 10 (3):297-304

Finch-Savage W.E., G. Leubner-Metzger. 2006. Seed dormancy and the control of germination. New Phytologist. 171: 501-523.

Gardner, F.,T., Pearce R.B., Mitchell, R.L., 2008. Fisiologi Tanaman Budidaya. Penerjamah Herawati Susilo, pendamping Subiyanto

Herdiawan dan Krisnan, 2014. kondisi lingkungan dengan jenis tanaman yang dibudidayakan. Bogor (ID) Institut Pertanian Bogor.

Karsono, S., Sudarmodjo, dan Y. Sutiyoso. 2002. Hidroponik Skala Rumah Tangga. Agromedia Pustaka. Jakarta

Kurniatyet, R., B. Budiman dan M. Suartana. 2010. Pengaruh media dan naungan terhadap mutu bibit suren (Toona sureni MERR). Jurnal Penelitian Hutan Tanaman 7: 77--83.

Kustyorini, T. I. W, Aju. T. N. K. dan Asroy. 2019. Frekuensi Penyiraman Larutan Urin Domba Terhadap Persentase Kecambahan, Persentase Kecambahan Normal, Produksi HIjauan Segar dan Produksi Bahan Kering Fodder Jagung (Zea mays) Dengan Sistem Hidroponik. Fakultas Peternakan Universitas Kanjuruhan Malang

Marsono dan Sigit. 2001. Petunjuk Penggunaan Pupuk. Penebar Swadaya, Jakarta.

McWilliams, D.A., D.R. Berglund, and G.J. Endres. 2000. Corn Growth and Management Quick Guide. Diakses pada tanggal 12 Desember.

Nasution, L.W. 2014.Percepatan Perkecambahan dan Pertumbuhan Kaliandra (Calliandra calothyrsus) Akibat Perendaman Pada Urine Hewan dan Pemotongan Benih.Skripsi. Medan: F. Pertanian USU.

Prihartini, R. 2014. Hydroponic Fodder Sebagai Pakan Alternatif Untuk Memenuhi Kekurangan Hijauan Bagi Sapi Perah Selama Musim Kemarau. Departemen Ilmu Dan Teknologi Pakan. Fakutas Peternakan IPB Bogor.

Rizqiani, F. N. Erlina A. dan Nasih W. Y. 2007.Pengaruh Dosis dan Frekuensi Pemberian Pupuk Organik Cair Terhadap Pertumbuhan dan Hasil Buncis (Phaseolus vulgaris L.) Dataran Rendah. Ilmu Tanah dan Lingkungan, 7 (1). 
Sarah dkk. 2016. Standar keberhasilan perkecambahan benih untuk dibudidayakan. Jurnal ilmiah mahasiswa pertanian.Universitas hasanudin Makasar. Volume I, Issue I, Agustus 2016, hal 1-9

Septia, H. 2016. Aplikasi Briket Campuran Arang Serbuk Gergaji dan Tepung Darah Sapi pada Budidaya Jagung Manis (Zea Mays sacchrata sturt) di tanah pasir pantai.Skripsi.Fakultas pertanian.Universitas Muhammadyah Jogjakarta.

Sneath R, McIntosh F. 2003. Review of hydroponic fodder production for beef cattle (bibliografi). Queensland (AU): Departemen of Primary Industies. 1 acuan dari database QUEESLAND GOVERMENT Okt 2003.

Subekti N. A., Syafruddin, Roy E., dan Sri S. 2010. Morfologi Tanaman dan Fase Pertumbuhan Jagung. Balai Penelitian Tanaman Serealia. Maros. Hal 16-27.

Sudarmodjo. 2008. Hidroponik. Tidak dipublikasikan. Parung Farm, Bogor

Suhardiyanto, H. 2009. Teknologi Hidroponik Untuk Budidaya Tanaman. Departemen Tehnik Pertanian. Fakultas Teknologi Pertanian IPB. Bogor. 28-40 Hal.

Sutedjo, R. 2002. Pertanian Organik Menuju Pertanian Alternatif dan Berkelanjutan. Penerbit Kasinius. Yogyakarta.

Sutopo L. 2010. Teknologi Benih. Jakarta: PT Raja Grafindo Persada 